Tobacco in sport

\section{Tobacco in sport: an endless addiction?}

A Blum

"They don't get your wind..."

$\mathrm{N}^{2}$ early all in tobacco control today can only imagine the early days television, when young sports fans watching their favourite team would be exposed to a steady stream of cigarette commercials featuring testimonials by top athletes. In the USA, overt cigarette advertisements have long since gone from the airwaves. Yet Formula One car racing, which reaches over 40 billion TV viewers each year, retains several tobacco sponsors whose brand logotypes and colours are constantly in view on the racing cars, banners, and drivers' uniforms. And although 1984 marked the last Olympic Games to have an official cigarette sponsor, in October China's largest cigarette company, Baisha, signed a 21 year old Olympic gold medallist hurdler to endorse a leading cigarette brand in print ads and commercials. "Everyone likes Liu Xiang and hopes he will soar higher and faster and maintain his sunny, healthy, progressive image," boasted the company's president. ${ }^{1}$

The connection between sports and tobacco is as old as professional athletic competition itself. Just a few years after teams in the National Baseball League began playing in 1876, trading cards with pictures of the players made their debut in cigarette packages. Numerous cigar and cigarette brands were named after sports-related themes. One brand of chewing tobacco, Bull Durham, advertised on outfield fences in baseball parks in the South, gave the name to the pitchers' warm up area behind the fence. A rare protest of the attempt to associate baseball and smoking occurred in 1911 when Hall of Fame second baseman, Honus Wagner, demanded that a cigarette company remove his picture from a tobacco trading card.

In the early decades of the last century, tennis, golf, swimming, football, track and field, skiing, and ice skating were often depicted in cigarette advertising as activities demanding a cigarette for enhanced performance and even good health. ${ }^{2}$ American Tobacco's Lucky Strike ads featured drawings of athletes with an obese shadow they would cast if they didn't smoke, and the accompanying slogan, "To keep a slender figure, reach for a Lucky instead of a sweet". From the 1920s through the 1940s when baseball was by far America's favourite sport, every team had a cigarette sponsor and the greatest baseball stars, including Babe Ruth, Joe DiMaggio, and Ted Williams, all appeared in cigarette ads. Lou Gehrig endorsed RJ Reynolds' Camels, claiming that they "don't get your wind, and I can smoke as many as I please".

\section{ALLAYING PUBLIC ANXIETY}

By the 1950s, filter tip brands were promoted by athletes on TV to allay the public's growing anxiety over reports linking smoking to lung cancer. The commissioner of baseball prohibited players from appearing in cigarette ads while in uniform, but the increasingly popular National Football League signed Philip Morris' Marlboro as its major television sponsor and permitted players to appear in tobacco ads. Anticipating restrictive federal regulation, the tobacco industry adopted a voluntary Cigarette Advertising Code in 1964 that stated it would not "depict as a smoker any person well known as being, or having been, an athlete... [or] any person participating in, or obviously having just participated in, physical activity requiring stamina or athletic conditioning beyond that of normal recreation". Testimonials from athletes and celebrities were also prohibited under the code. Evidence shows the industry blithely ignored its own guidelines. ${ }^{3}$

In 1969 when Congress banned cigarette advertising on TV and radio, Joseph Cullman, chairman of Philip Morris, promised Congress never again to use athletes to promote cigarettes. Yet when the law went into effect in 1971, tobacco companies merely shifted their TV advertising expenditures into the creation and sponsorship of televised sporting events, the net result being a more cost effective and less hard sell way to retain cigarette brand imagery.

\section{CORPORATE SPONSORSHIP}

Among nationally televised sporting events that emerged in the early 1970s were Philip Morris' Virginia Slims Women's Tennis Circuit and Marlboro Cup horse race, and RJ Reynolds'
Winston Cup NASCAR (National Association of Stock Car Racing) Race Series. The appearance in 1983 of a weekly column in The Wall Street Journal, entitled "KENT Sports Business" and produced by Lorillard's KENT cigarette brand, reflected the influx of corporations to sports sponsorship as a hot advertising trend. By 1990 more than 20 different televised cigarette sponsored sports existed in the USA alone, including eight different forms of motor racing. With just two exceptions out of 28 teams, every major league baseball stadium featured prominent outfield billboards for either Marlboro or Winston cigarettes. ${ }^{2}$ A similar scenario existed in the National Football League and National Basketball Association. (The National Hockey League had banned such ads from its rinks in 1981.) Although television advertising for oral tobacco products was prohibited in 1986, leading manufacturers would not be denied their opportunity to circumvent the ban. Led by UST (now USST, or United States Smokeless Tobacco Company), makers of SKOAL and Copenhagen, and Swedish Match, producer of Red Man Chew, they began sponsoring rodeo, drag racing, stock car racing, monster trucks, and other risky sports shown on TV.

By 1994 RJ Reynolds acknowledged sponsoring 2736 separate sporting events each year, including the nationally televised Winston Cup races, which spawned a weekly TV programme "Inside Winston Cup Racing". Winston cigarettes were given out at auto races by attractive looking women. Thousands of young men lined up before each race to pose for a photograph with Miss Winston. Commercials for Winston were shown throughout the race on electronic scoreboards, and videotapes featuring these ads were given away to fans who visited the numerous Winston kiosks located around the stadium.

The press acquiesced in the promotion of smoking through sports, refusing to drop the cigarette brand names from the coverage of events, invariably referring to a NASCAR event solely as Winston Cup or to the women's professional tennis tour as "The Virginia Slims" or "The Slims". Leading newspapers including the Miami Herald, the Houston Chronicle, and the Los Angeles Times were co-sponsors of such events.

\section{COUNTER MEASURES}

Beginning in the late 1970s efforts were made to counteract tobacco sponsorship of sports in the USA. In 1977 the physicians health promotion group Doctors Ought to Care (DOC) started 
purchasing counter advertising space in several cities on billboards and bus benches, in newspapers, and on TV and radio, and began a 20 year series of satirical "housecalls" at tobacco sponsored events such as the Virginia Slims Tennis Tournament and the Marlboro Ski Challenge. Intended to inspire major health organisations and the business community to put significant funding into breaking the tobaccosports connection, DOC's creations included the Emphysema Slims Tennis Tournament, the Barfboro Barfing Team, and the Dead Man Chew Softball League. The group also sponsored a motorcycle racing team, a drag racing car, little league baseball teams, a racing sailboat, and the US Boomerang Team, which won the world boomeranging championship in 1988 wearing uniforms with a prominent no-smoking logo. In the 1980s Surgeon General C Everett Koop, Secretary of Health and Human Services Louis Sullivan, and Representative Henry Waxman were all outspoken in their condemnation of tobacco sponsorship of sports. However, both Democratic and Republican administrations remained silent until the Justice Department under President Clinton acted to enforce the Congressional ban on cigarette brands on TV.

Since 1994, a valiant if as yet unsuccessful attempt has been made by the National Spit Tobacco Education Program (NSTEP) to reduce oral tobacco use by professional and amateur baseball players (http://www.nstep.org). One of the spokespersons for this educational campaign was former Detroit Tigers pitcher Bill Tuttle, who developed oral cancer caused by his use of smokeless tobacco. His mutilating surgery and personal suffering until his death in 1998 served as a stark reminder of the horrific consequences of smokeless tobacco.

Until the Master Settlement Agreement (MSA) of 1998, televised tobacco sponsored sporting events were ubiquitous on both network and cable TV. Limited to one sports sponsorship per brand under the MSA, the cigarette companies' TV presence dropped precipitously. The decision by RJ Reynolds to pull its sponsorship of NASCAR at the end of the 2003 season marked the end of its lavish spending on sports. Thirty years after the passage of the bill to ban cigarette commercials from TV, the company was still reaping the rewards of enormous exposure of its flagship brand on national TV. Today tobacco sponsored motor sports are still a mainstay of the Speed Channel. Marlboro is still getting its fair share of global TV attention through the telecast of Formula One racing; and in the USA it is seen weekly on $\mathrm{ABC}$ and ESPN through races on the IndyCar Circuit. Rodeos sponsored in part by USST (and where children are still admitted free) are telecast on the Nashville Network. Athletic imagery predominates in Marlboro's Unlimited magazine (intended by the company to be available only by mail to smokers over the age of 21). Advertisements for SKOAL in popular men's magazines such as FHM and Maxim feature images of extreme sports.

ORAL TOBACCO STILL A PROBLEM

Thus the influence remains, less ubiquitous perhaps than at any time in the past half century but all the more outrageous, considering what we have since learned about tobacco's devastat- ing health toll. Regrettably, as Severson et $a l^{5}$ point out in this issue of Tobacco Control, usage of oral tobacco by young professional athletes remains a major problem nearly three decades after Christen and colleagues ${ }^{6}$ brought this growing epidemic to the attention of the public. In spite of the 1991 ban on oral tobacco in minor league baseball, the situation continues to be terribly disheartening. With the harm reduction movement all too willing to endorse smokeless tobacco as a less dangerous alternative to smoking, and the manufacturers promoting the product more aggressively than ever, we can only muse that the ongoing association of tobacco products and sports will have left a bitter taste in our mouth for decades to come.

Tobacco Control 2005; 14:1-2.

doi: $10.1136 /$ tc. 2004.010728

Correspondence to: Professor Alan Blum, The Center for the Study of Tobacco and Society, The University of Alabama School of Medicine, Tuscaloosa, Alabama 35401, USA; ablum@ cchs.ua.edu

\section{REFERENCES}

1 Jenkins BJ. Chinese hurdler lands a smoking deal. USA Today October 22, 2004: C1

2 Blum A. Tobacco industry sponsorship of sports: a growing dependency. In: Durston B, Jamrozik K, eds. Tobacco and health 1990, the global war: Proceedings of the Seventh World Conference on Tobacco and Health. Perth, Australia: Health Department of Western Australia, 1990:882-4.

3 Blum A. The Marlboro Grand Prix: circumvention of the television ban on tobacco advertising. N Engl J Med 1991:324:913-17.

4 Clarke L. Will attacks on tobacco slow NASCAR's show? Charlotte Observer. May 21 1994: A1,14.

5 Severson HH, Klein K, Lichtenstein E, et al. Smokeless tobacco use among professional baseball players: survey results, 1998 to 2003. Tobacco Control 2005; 14:31-6.

6 Christen AG, McDaniel RK, Doran JE. Snuff dipping and tobacco chewing in a group of Texas college athletes. Texas Dental Journal 1979;97:6-10. 